\title{
ON A DISEASE OF COCOA AND COFFEE FRUITS CAUSED BY
} A FUNGUS HITHERTO UNDESCRIBED.--Liberian coffee cultivated in the Gold Coast Colony is subject to a disease which attacks the fruit, and which may be so prevalent in wet seasons as to endanger the whole crop.

The first indication of the disease is a dark purplish-brown discoloration of the berry, which later becomes covered with a white or pinkish-brown mealy incrustation formed by the conidia of a fungus always associated with the disease.

Fruits of all ages may be attacked, but the disease is most serious in the case of young berries, which are arrested in development and eventually become shrivelled and hard.

The same fungus is also responsible for a disease of cocoa fruits. Cross inoculations from Liberian coffee to cocoa fruits, and from cocoa to the fruits of Liberian coffee, have been effected and have given the characteristic symptoms of the disease, from which in both cases the fungus herein described has been reclaimed in cultures.

In natural infections of cocoa the symptoms of the disease-locally known as Mealy Pod-are similar to those caused by Phytophthora Faberi, Maub; the point of infection becomes brown, the area of discoloration darkens and increases rapidly until, given suitable conditions of moisture, the whole pod is involved; the mealy masses of conidia, at first white but later tending to become pinkish-brown, which have originally emerged as small pustules, form masses so dense that the pod becomes encrusted, and the pericarp of the fruit is decomposed. The encrusted masses of conidia are the most obvious of the symptoms which distinguish this disease from that caused by Phytophthora.

Such infection experiments as have been conducted have not given conclusive results as to the parasitology of the fungus; they tend, however, to indicate that it develops much more readily on wounded or moribund fruits than on healthy ones. It has never been found on the vegetative parts of its hosis. From an economic point of view its occurrence is important, because a large number of pods on a cocoa farm are normally wounded by various natural agents, and are thus liable to infection. The effect of the disease is particularly serious when young pods are infected, as the fungus is able to reach and to destroy the seeds in those cases where the sclerotic tissues, found in the fully developed pod, have not been formed.

The fungus responsible for the disease produces in the tissues of the host a nonseptate mycelium of comparatively coarse hyphae, which spreads rapidly through the intercellular spaces. No haustoria have been observed, but, from the intercellular hyphae, branches arise of smaller diameter which penetrate the walls of the host cells, branch freely, and pass from cell to cell. The cells thus attacked are killed and their contents become discoloured. 
When the mycelium is well established in the host tissues it proceeds to the formation of conidia. Hyphae collect beneath the epidermis and form a subiculum on which arises a dense mass of conidiophores, and this leads to the rupture of the overlying epidermis. The conidiophores are very variable in form. The simplest

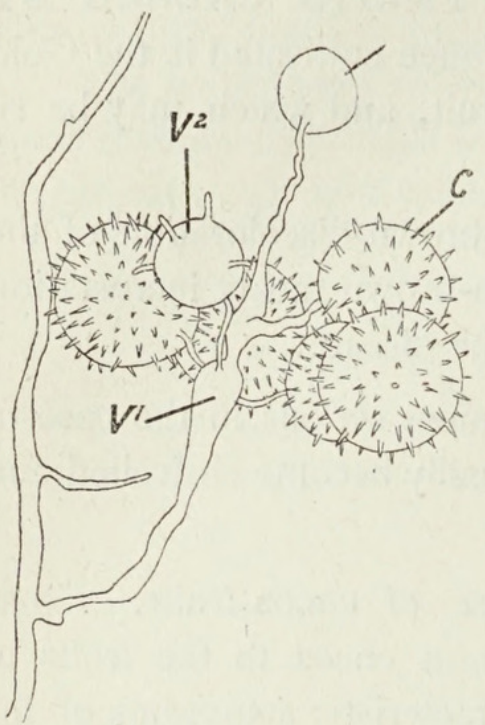

FIG. I. Conidiophore show ing swollen vesicle, $v^{1}$, with whorl of 5 conidia, $c$, and a secondary vesicle, $v^{2}$, on which conidia are beginning to develop. $\times 750$. ones are upright hyphae terminating in a single conidium, but more usually the conidiophore bears a terminal vesicle to which a whorl of pedicellate conidia is attached. The more complex types may show a series of such enlargements, each with a whorl of conidia or with lateral fertile branches replacing some of the latter.

The conidia are spherical in form, strongly echinulate, with an average diameter of $35 \mu$ borne on pedicels which vary in length up to $30 \mu$.

Not only are conidia produced on the outer surface of the fruit, but in Theobroma they are found on the inner surface of the ovary wall, in mucilage sacs or even in the wider intercellular spaces.

The conidia found in the internal cavities of the fruit are often of larger diameter than the normal type and invariably have much thicker walls; they are perhaps better regarded as chlamydospores. Their germination has not been observed.

The conidia germinate readily both in water and in nutrient solutions. In all cases so far observed they produce a germ tube, which under suitable conditions gives rise to a mycelium on which the characteristic conidia are developed. The fungus is thus readily grown on artificial media, and pure cultures have been established and used in infection experiments.

Sexual Reproduction. The tissues of diseased cocoa pods bearing the characteristic conidia show also an abundance of sexual organs of Peronosporineae type. These are almost invariably found inside the host cells, singly or in groups; very rarely they may occur in the mucilage cavities of the pericarp. They arise from the intracellular branches of the mycelium, and may have associated with them groups of rounded vesicles. The oogonia are small, averaging $40 \times 24 \mu$, rather thick-walled, and characterized by the presence of irregular sac-like outgrowths. These latter structures vary considerably in size and shape, from short rounded bosses to long finger-like processes, often curved and sometimes even faintly forked. The antheridia are amphigynous, completely surrounding the stalk of the oogonium in the manner hitherto only described for species of Phytophthora by Pethybridge ${ }^{1}$ and Dastur. ${ }^{2}$

1 Pethybridge, G. H.: On the Rotting of Potato Tubers by a New Species of Phytophthora having a Method of Sexual Reproduction hitherto undescribed. Sci. Proc. Roy. Dublin Soc., N. S., xiii, No. 35, I 913, p. 529 .

Lafferty, H. A., and Pethybridge, G. H.: On a Phytophthora parasitic on Apples which has both Amphigynous and Paragynous Antheridia; and on Allied Species which show the same Phenomenon. Ibid., xvii, No. 4, 1922, p. 29.

2 Dastur, J. F.: On Phytophthora parasitica, nov. spec. Mem. Dept. Agr. India, v, No. 4, I9I3, pp. I $77^{-2} 3$ I. 
The general relations between the sexual organs is similar to that described by these authors. The antheridium, which is usually terminal, but may be intercalary, is penetrated by the oogonial branch, which then enlarges above to form the oogonium.

It is of interest to record that in ripe oogonia, obtained from old desiccated pods, the antheridia become readily detached, and then show that their walls are intact, and that a definite antheridial membrane surrounds that of the stalk of the oogonium. This might be expected from a study of the early stages of penetration, but it is impossible to distinguish the double membrane in sections of the mature oogonium.

The material so far available has not been suitable for cytological work, but

A

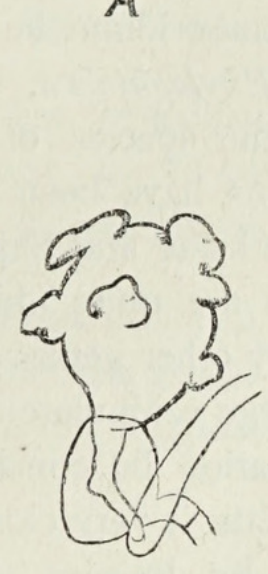

$B$

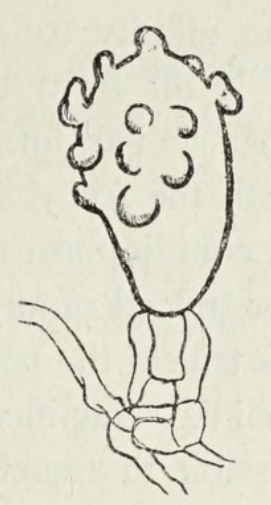

C

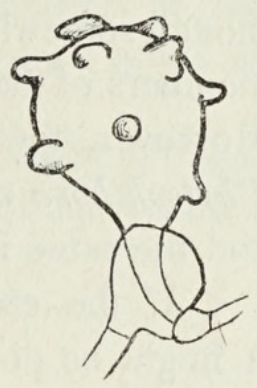

$D$

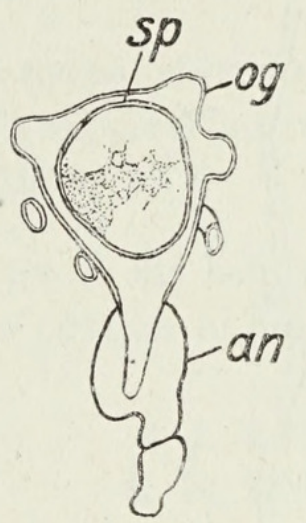

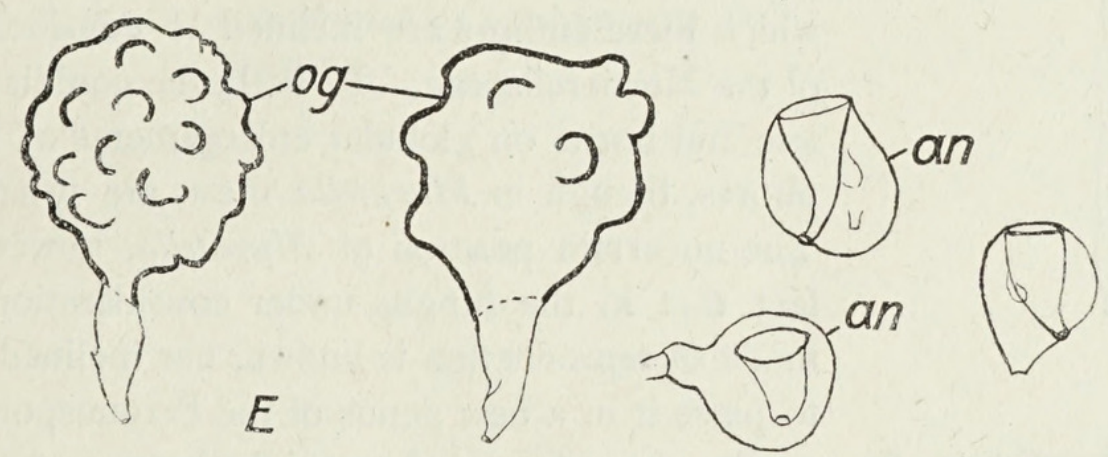

FIG. 2. A, B, C, oogonia from cells of mesocarp of cocoa pod, showing the numerous sacculae and amphigynous antheridia; D, section of oogonium with ripe oospore; E, oogonia with detached antheridia found in desiccated material three and a half months old. an., antheridium; og., oogonium; sp., oospore. $\times 600$.

preliminary observations show that the young oogonium is multinucleate, that little or no periplasm remains after the delimitation of the oosphere, and that the oosphere and ripe oospore are uninucleate. The oospore has a comparatively thin wall with little or no epispore. All attempts to germinate the oospores have so far failed of results.

That a definite relation existed between these sexual organs and the conidialbearing mycelium, was evident from their constant association and from the fact that healthy pods, infected with the conidia, showed subsequently the presence of oogonia. Any doubts existing have, however, been set at rest by tracing the continuity of hyphae bearing conidia with those bearing oogonia, in mycelia from artificial cultures. These were tube cultures in which both sterilized cocoa pod and a cocoa pod agar were employed.

Up to the present no sexual organs have been found either in the tissues of the coffee pericarp or in artificial media prepared from coffee fruits. 
The facts detailed above make it clear that we are concerned with a member of the Peronosporineae which cannot readily be referred to any of the existing genera,

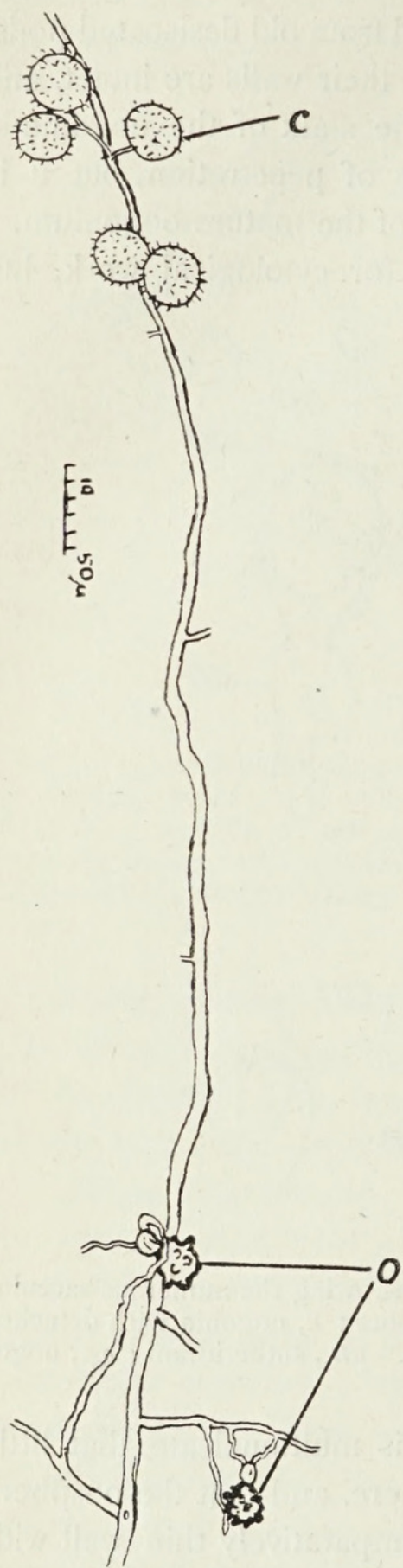

FIG. 3. Portion of mycelium from artificial culture showing conidia, $c$, and oogonia, 0 . $\times$ I 40 . though certain of the facts detailed above indicate a close relation to the genus Phytophthora. The amphigynous antheridium has hitherto been found only in certain species of this genus, and Lafferty and Pethybridge (loc. cit.) in a recent communication have given a list of fourteen species in which this type of antheridium has been found, either alone or associated with the paragynous form, whereas in five species the latter has alone been recorded.

If the character of the antheridium be regarded as indicating some affinity to Phytophthora, the sacculate oogonia mark it off from the species of this genus, though somewhat similar forms have been described in members of both the Ancylistineae and Saprolegnineae. Moreover, the conidiophores are quite unlike those of Phytophthora or indeed of any other genus of the family, and the same is true of the large echinulate conidia.

If the conidial fructification be considered alone, it might be possible to associate it very closely with the genus Muratella, described by Bainier and Sartory, ${ }^{1}$ which these authors are inclined to consider a member of the Mortierellaceae. In both, the conidia are echinulate and borne on globular enlargements of the conidiophores, though in Muratella these are usually terminal. The uncertain position of Muratella, however, and the fact that in the fungus under consideration the sexual mode of reproduction is known, has inclined the authors to place it in a new genus of the Peronosporineae, based on the characters of the conidiophores and the sacculate oogonia, under the name of Trachysphaera fructigena.

Trachysphaera, nov. gen. ( $\tau$ paxús $=$ rough, $\sigma \phi a i p a=$ globe).

Conidiophorum simplex vel ramosum vesiculis terminalibus vel intercalaribus conidia pedicellata gerentibus praeditum.

Antheridia amphigynosa. Oogonia pyriformia e bulloso alte tuberculosa, oosporas episporio tenui vestitas liberas continentia.

\section{Trachysphaera fructigena, nov. sp.}

Mycelium intercellulare plerumque continuum non-septatum e hyphis crassiusculis compositum; haustoriis nullis.

${ }_{1}$ Bainier, G., et A. Sartory: Étude morphologique et biologique du Muratella elegans. Bull. Soc. Mycol. France, xxix, I9I 3, pp. I 29-36. 
Conidiophorae erectae plerumque vesiculo terminali conidiorum pedicellatorum ( I-6) verticillium gerente praeditae, interdum evesiculiferae conidio singulo apicali ornatae, interdum vesiculorum (cuiusque vel conidiorum vel conidiorum cum ramulo verticillium gerentis) catenam praebentes.

Conidia sphaerica echinulata $I_{3}-48 \mu$ (plerumque $c .35$ ) leptodermia hyalina, pedicillis $10-30 \mu$ longis." Chlamydosporae intercellulares echinulatae pachydermes.

Antheridia amphigynosa plerumque terminalia. Oogonia pyriformia parva (plerumque $c .40 \times 24 \mu$ ) satis pachydermia, tuberculis sacculiformibus irregularibus multiformibus tum brevibus obtusis tum longis dactyliformibus rectis vel curvatis raro subfurcatis insigniter exornata.

Hab. in fructu Coffeae libericae et Theobromatis Cacao.

The further investigation of problems connected with the parasitism of the fungus is being actively carried on by one of the authors in the Mycological Laboratory of the Department of Agriculture of the Gold Coast Colony at Aburi.

The authors desire to record their grateful appreciation of the help rendered by Mr. J. Ramsbottom in the consideration of the systematic position of the fungus and in drawing up the diagnosis.

R. J. TABOR.

R. H. BUNTING.

Imperial College of Science and Technology, LONDON. 


\section{$2 \mathrm{BHL}$ Biodiversity Heritage Library}

Tabor, R.J and Bunting, R. H. 1923. "On a disease of cocoa and coffee fruits caused by a fungus hitherto undescribed." Annals of botany 37, 153-157. https://doi.org/10.1093/oxfordjournals.aob.a089833.

View This Item Online: https://www.biodiversitylibrary.org/item/270686

DOI: https://doi.org/10.1093/oxfordjournals.aob.a089833

Permalink: https://www.biodiversitylibrary.org/partpdf/319076

\section{Holding Institution}

New York Botanical Garden, LuEsther T. Mertz Library

\section{Sponsored by}

BHL-SIL-FEDLINK

\section{Copyright \& Reuse}

Copyright Status: Public domain. The BHL considers that this work is no longer under copyright protection.

This document was created from content at the Biodiversity Heritage Library, the world's largest open access digital library for biodiversity literature and archives. Visit BHL at https://www.biodiversitylibrary.org. 